\title{
レジン充填の表面亀裂と仕上げ研秃法 の影響について
}

\author{
井上，雅臣平、野忠彦 \\ 東京医科歯科大学保存学教室（指澊：総山孝雄教授）
}

(炤和 36 年 5 月 16 日受付)

\section{Crazing of Acrylic Fillings and the Influence of Finisning and Polishing.}

\author{
by \\ Masaomi Inoue and Tadahiko Hirano \\ Department of Operative Dentistry, Tokyo Medical \\ and Dental University
}

即時重合レジンは, その優れた特性によつて, 従 来硅酸セメント,アマルガムあるいは Metal Inlay でも充填が困難であつた根面蟼蝕, 揳状欠損の充 填を容易にし，特に審美的要求の強いIV級扔よび 前歯部VI級窩洞の充填では, 総山1 ${ }^{1)}$ の考案による 䤼骨保持等の新しい方法によつて, 硅酸セメント では見られなかつた成果をあげている。従つて， その適応範囲も広くなりその需要は日々に増大し ている。しかしながら未だ必ずしも満足の出来な い欠点も 2,3 残つて抢り，その 1 つとして充填 物の変色の問題がある。

レジン充坥物の変色の原因としては，レジン自 体の化学的変化および外部からの污染が考えられ る。しかし最近の製品では，変色の原因となる硬 化促進剂としての芳香族第 3 級アミン，あるいは 重合抑制剤としてのハイドロキ/ンの添加量の調 節により化学的変化による変色は著しく少なくさ れていると云われる。さきに総山らの行つた臨 林試験成績でも，充塡総数 117 例中変色したもの 10 例を認めたが，これらはいずれも口腔清掅の悪 い患者で，しかも歯垢などの貯溜している場所の 充塡物に多く見られたので，污染による変色であ
るらしいと報告されている。

かような污染による変色は, もしレジン充填の 表面に無数の亀裂があれば,一そう起り易いもの と想像される。

加熱重合レジンの刍裂発生に関してはすでに数 多くの報告がある。Skinner ${ }^{3)}$, Sweeney"), 河野5) らは, 加熱重合レジンの表面にアルコールあるい は acrylic monomer を作用させて刍裂の生じるこ とを報告している。Körber ${ }^{6)}$ および Meyer") は加 熱重合レジンを苛激に研磨し，そこに有機溶剂を 作用させると亀裂を生じると云つている。また吉 田ら ${ }^{8)}$ は C.C., F.C., ユージノールなど円歯科常 用薬剤によつて継続歯の前装レジンが侵襲を受け た例を報告している。

そこで, 即時重合のレジン充堤の場合でもこの 様な亀裂が発生するかどうかが重要な問題となる ので，われわれはレジン充填の表面亀裂の起り方 ならびにその深さ,さらに各種填塞仕上げ研磨法 による影響について実験を行つた。

\section{実験方法}

1. 実験材料 
透明即時重合レジン（松風社製パイルAより色 素を除いて特製したもの)

2. 試片の調製

A. 窩洞 内径約 $3 \mathrm{~mm}$, 高さ約 $8 \mathrm{~mm}$ の硝子 管(図 1 のa)を用い，その底部約 $3 / 4$ に燐酸セメン 卜を填塞して曧底を作り（図1のb), 開放された 上部より室温でレジン充填を行つた（図 1 の d)。

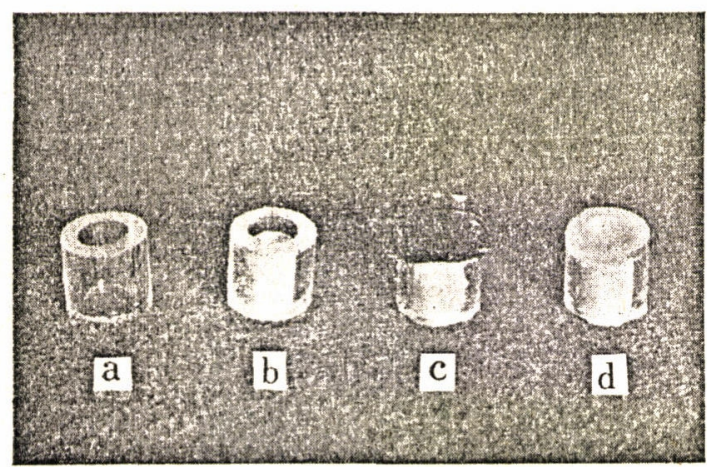

a. 硝子管 b. 燐酸セメントを填塞した窝洞

c. レジンを塂塞し錫箔を貼布

d. 錫䇴を剝離した試片 :

図 1 試 片

B. 填塞法 次の 2 種類の方法で塡塞した。

i）筆積み法 前述の窩洞内に通法に従つて, 小筆の先にとつた粉液混合体を反復積層して大体 $5 \sim 6$ 回で窝洞を充たし, 直ちに錫箔で被覆して 硬化を待ち, 錫箔剥離後硝子管ごと $37^{\circ} \mathrm{C}$ の蒸溜 水中に 24 時間浸漬し, 取出したものを試片とし た。一部の試片では塡塞後錫箔を貼布しなかつ た。

ii） 加圧充塡法 即時重合レジンの粉末 $2 \mathrm{~g}$ に 対して液 $1 \mathrm{cc}$ を加え, これが餅状になつた時前述， の窩洞に塡入し, その上に錫䇴を貼布し,さらに モデリングコムパウンドで作つた圧子により态塡 圧 $1 \mathrm{~kg}$ で加圧硬化させ, 錫箔剥離後硝子管ごと $37^{\circ} \mathrm{C}$ の蒸溜水中に 24 時間浸漬した。

C. 仕上げ研磨法 充填物の表面は, 仕上げ研 磨を行なつたものと行わなかつたものとが比較さ れた。

仕上げ研磨方法としては次の 4 種類が試みられ
た。

i）仕上げは乾いた仕上げ用バーで行ない，研 磨はごく少量の浮石末泥を用いほとんど乾燥した 状態で, しかもラバーカップを押しつけるように して行なつた。

ii）仕上げは乾いた仕上げ用バーで行ない，研 磨は通法に従つてラバーカップに浮石末泥を充分 つけて荒磨きし，さらに亜鉛華泥で研磨した。

iii）仕上げは乾いたカーボランダムポイントで 行ない, 研磨は通法に従つてラバーカップに浮石 末泥㧍よび业鉛華泥を充分つけて研磨した。

iv）注水しながらカーボランダムポイントで仕 上を行ない, 研磨は浮石末泥, 亜鉛華泥を充分つ けて行なつた。

3. 亀裂観察方法

A. アルコール浸漬 前述の方法で調製した試 片を 24 時閒後に蒸溜水中より取出し,レジン表面 の水分を濾紙で充分吸取り乾燥させた。次に予め 用意しておいた $10 ， 20 ， 30 ， 40 ， 50 ， 60 ， 70 ， 80$ ， $90,100 \%$ の各種濃度のエチールアルコールを各 群 50 コの試片の表面に 30 秒間づつ作用させた。 アルコールはいわゆる無水アルコールを硫酸銅で 処理して，さらに一そう純にしたものを $100 \%$ ア ルコールと考えて使用した。

B. 染色と観察 アルコールを作用させた試片 、の亀裂の観察を容易にする目的でヨード染色を行 なつた。すなわち, $37^{\circ} \mathrm{C}$ の恒温水槽中に保管し たヨードヨードカリ溶液中にこれらの試片を 12 時間浸漬した。なお, このヨードヨードカリ溶液 への浸漬だけではレジン表面に亀裂の生じないこ とを予め確認しておいた。ヨードヨードカリ溶液 中より取出した試片を $37^{\circ} \mathrm{C}$ の蒸溜水中で良く洗 い過剩のヨードヨードカリ溶液を除いてから，レ ジン表面の亀裂発生状況を倍率 50 で 鏡検比較観 察した。

4. 亀裂発生部削除後の再試験

筆積み法によつてレジンを塡塞し，錫䇴を剝離 後仕上げ研磨しなかつた試片に $100 \%$ \% ルコール を 30 秒間作用させ， ヨード染色によつて亀裂の 存在を確認した後, 亀裂が消失するまでその表面 
表 1 各実験群 5 例中の亀裂発生率例数

\begin{tabular}{|c|c|c|c|c|c|c|c|c|c|c|c|c|}
\hline \multicolumn{3}{|r|}{ アルコールの濃度 (\%) } & 100 & 90 & 80 & 70 & 60 & 50 & 40 & 30 & 20 & 10 \\
\hline \multirow{3}{*}{ 筆 } & \multirow{2}{*}{ 錫 } & 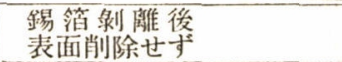 & 5 & 5 & 5 & 5 & 5 & 0 & 0 & 0 & 0 & 0 \\
\hline & & $\begin{array}{l}\text { 乾いたバで仕上げ,乾い } \\
\text { たラバーカップで研磨 }\end{array}$ & 1 & 0 & 0 & 0 & 0 & 0 & 0 & 0 & 0 & 0 \\
\hline & \multirow{3}{*}{$\begin{array}{l}\text { 貼 } \\
\text { 布 }\end{array}$} & $\begin{array}{l}\text { 乾いたバーで仕上げ } \\
\text { 浮石末典鉛華で研磨 }\end{array}$ & 4 & 2 & 0 & 0 & 0 & 0 & 0 & 0 & 0 & 0 \\
\hline 積 & & $\begin{array}{l}\text { 乾いたポイントで仕上げ } \\
\text { 浮石末, 画鉛華で研磨 }\end{array}$ & 0 & 0 & 0 & 0 & 0 & 0 & 0 & 0 & 0 & 0 \\
\hline \multirow[t]{2}{*}{ 法 } & & $\begin{array}{l}\text { 湶つたポイントで佶上げ } \\
\text { 浮石, 鉛華で研磨 }\end{array}$ & 1 & 2 & 0 & 0 & 0 & 0 & 0 & 0 & 0 & 0 \\
\hline & $\begin{array}{l}\text { 錫 } \\
\text { 表 }\end{array}$ & 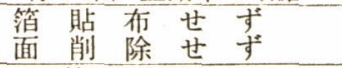 & 5 & 5 & 5 & 5 & 5 & 0 & 0 & 0 & 0 & 0 \\
\hline \multirow{2}{*}{$\begin{array}{l}\text { 加 } \\
\text { 压 } \\
\text { 充 } \\
\text { 锄 }\end{array}$} & \multirow{2}{*}{$\begin{array}{l}\text { 錫 } \\
\text { 箲 } \\
\text { 貼 } \\
\text { 布 }\end{array}$} & $\begin{array}{l}\text { 錫箔剝離後 } \\
\text { 表面削除せ哭 }\end{array}$ & 5 & 5 & 5 & 5 & 5 & 5 & 5 & 0 & 0 & 0 \\
\hline & & $\begin{array}{l}\text { 乾いたボイントで估上げ } \\
\text { 浮石末，亜鉛華で研磨 }\end{array}$ & 0 & 0 & 0 & 0 & 0 & 0 & 0 & 0 & 0 & 0 \\
\hline
\end{tabular}

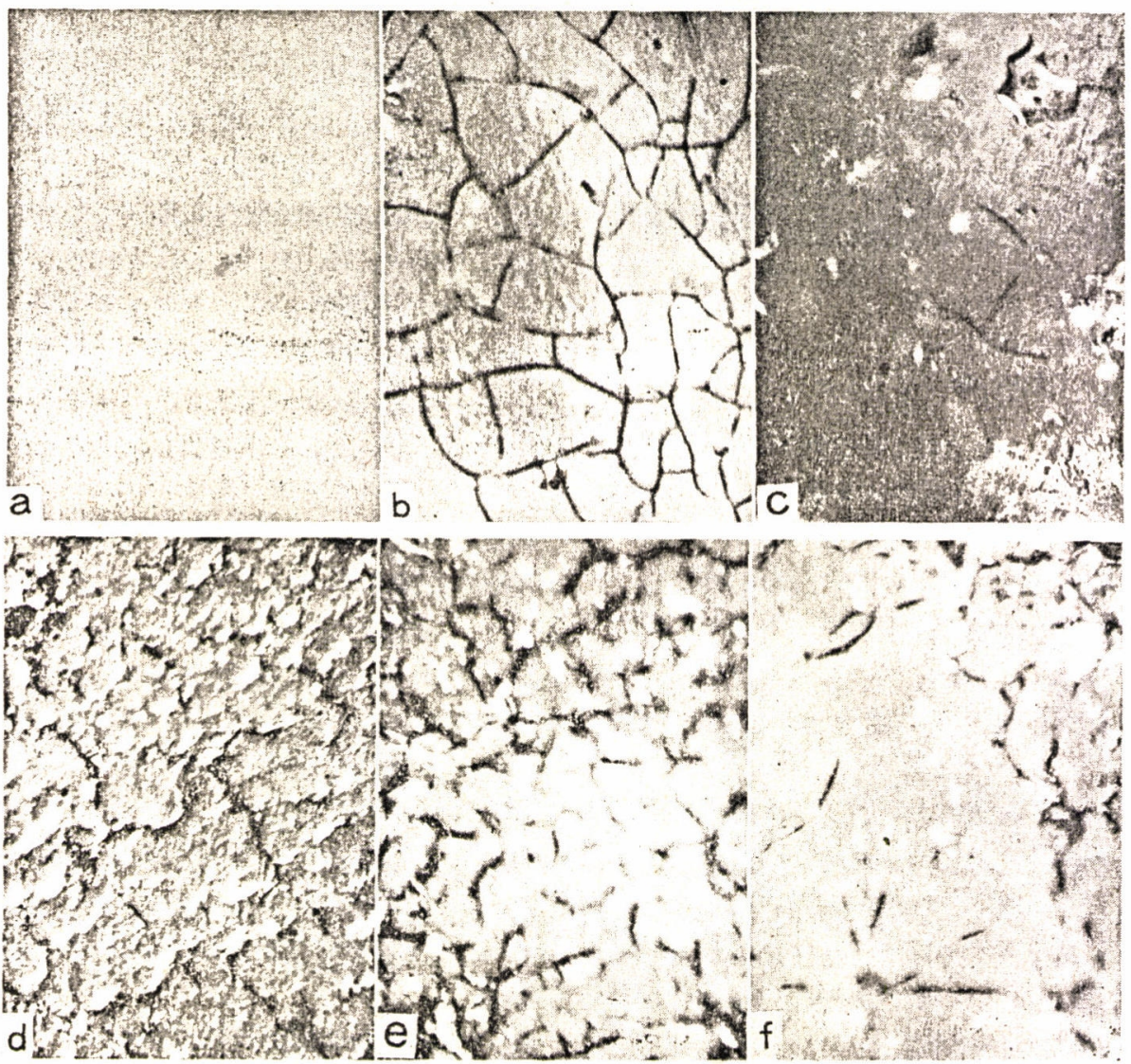

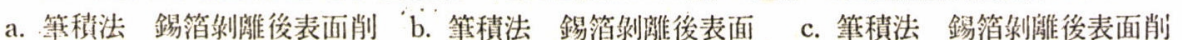
除研磨す $100 \%$ \%ルコール＼cjkstart削除せず $100 \%$ アルコール＼cjkstart除せず $60 \%$ ア ア ルール

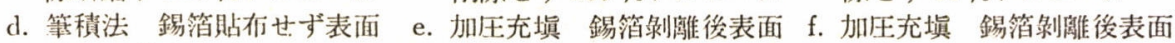
削除せず 100 \%アルコール 削除せず $100 \%$ アルコール＼cjkstart削除せず $60 \%$ \%アコール

図 2 各種塡塞法によるレジンの表面亀裂 
を乾いたカーボランダムポイントで削除した。こ の試片に再び各種濃度のアルコールを作用させて 亀裂が再発するかどうかを調べた。

\section{実 験 成 縤}

1. 填塞, 仕上げ研磨法と亀裂発生との関係

表 1 に示す如く，筆積み法にようたもので，錫 䇴を剥雄したままで表面の仕上げ研磨を行わなか つたレジンの表面では $60 \%$ 以上のアルコールに より，程度の差はあるが，全て亀裂の発生が見ら れた。(図 2 の b c c)

表面の仕上げ研磨を行なつたものでは，90\% 以上のアルコールを作用させたものに僅かに龟裂 の発生が見られたが，一般に亀裂はほとんど生ぜ ず(図のa)，仕上げ研磨の方法による明かな成績 差は無いようであつた。

次に，璂塞後錫䇴を貼布しなかつたものでは， 表面は極めて粗造であり（図のd），観察がやや困 難であつたが，表 1 に示す如く $60 \%$ 以上のアル コールにより亀裂の発生を認めた。しかしその発 生の程度は 錫䇴貼布群より幾分軽いようであつ た。

一方加圧充填群においては，仕上げ研磨を行わ なかつたものでは亀裂の発生が最も著しく（図の e,f)，40\%アルコールですでに亀裂の発生が見ら れた。しかし仕上げ研磨を行なつたものではいず れも亀裂の発生を見なかつた。

2. 亀裂の樑さ

亀裂の生じた試片を硝子管から取出し, その横 断面を作り接眼測微計で亀裂の深さを測定した。 表 2 は龟裂の発生した各群の $100 \%$ アルコールに

表 2 各種填塞法による亀裂の深さ

\begin{tabular}{|c|c|c|c|}
\hline & & \multicolumn{2}{|c|}{ 亀裂の深さ } \\
\hline & & 平均 & 最 大 \\
\hline \multirow{2}{*}{$\begin{array}{l}\text { 箨 } \\
\text { 積 } \\
\text { 法 }\end{array}$} & 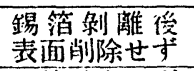 & $40 \mu$ & $49 \mu$ \\
\hline & $\begin{array}{l}\text { 傷皦貼有せず } \\
\text { 表面削除せず }\end{array}$ & $30 \mu$ & $37 \mu$ \\
\hline $\begin{array}{l}\text { 加充 } \\
\text { 圧填 }\end{array}$ & 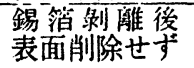 & $75 \mu$ & $110 \mu$ \\
\hline
\end{tabular}

よる亀裂の深さの比較である。

筆積み法によつて填塞し, 錫䈃剝離後仕上げ研 磨しなかつた試片の亀裂の深さは, アルコールの 濃度による差はほとんどなく，平均 $40 \mu$, 最大 49 ルであつた（図 3 の b, c)。

錫箔を㙋布せず，しかも仕上げ研磨をしなかつ た試片においては，表面の凹凸が激しく測定がや や困難であつたが，一般に亀裂は幾分浅く，最大 $37 \mu$ でアルコールの濃度によつて亀裂の深さに はほとんど差が見られなかつた（図のd）。

加圧充填群で仕上げ研磨を行わなかつたものに おいては，亀裂が著しく深くなつており，最大 $110 \mu$ に及んだ（図のe)。そして濃度の高いアル コールの方が幾分深い亀裂を作つているように思 われた。

3. 亀裂発生部を削除した後の亀裂再発

亀裂発生部を削除した面に再びアルコールを作 用させた実験では，実験試片 30 コの内 1 例も亀 裂の再発生を涊めることができなかつた。

\section{考 察}

1. 争裂発生の原因について

現在まで加熱重合レジンの亀裂発生に関する研 究は, 多くの材料学者あるいは臨床家によつて, 種々な方法によつて行われ，その報告も数多くあ る。

1958 年 Sweeney, 1959 年河野は 既製レジン歯 および加熱重合レジンの表面に acrylic monomer あるいはアルコールを作用させて亀裂が生じるこ とを確め，その原因として，重合硬化途中にお ける acrylic monomer の収縮により polymer と polymer の間に引張りの力が働き, その結果生じ た忘力が成型後内部に残留し，このような成型物 に有機溶剤を接触させると表面が溶解されて,内 部応力が解放され亀裂が生じるし，さらに重合操 作中に加わる外力ならびに冷却時の収縮によつて 生じた応力も加わるものであるとしている。1959 年亀田ら ${ }^{91}$ も加熱重合レジンの俺裂発生の実験を 行ない，その原因について次のごとく考察してい る。すなわち, 亀裂が発生する原因が内部応力分 

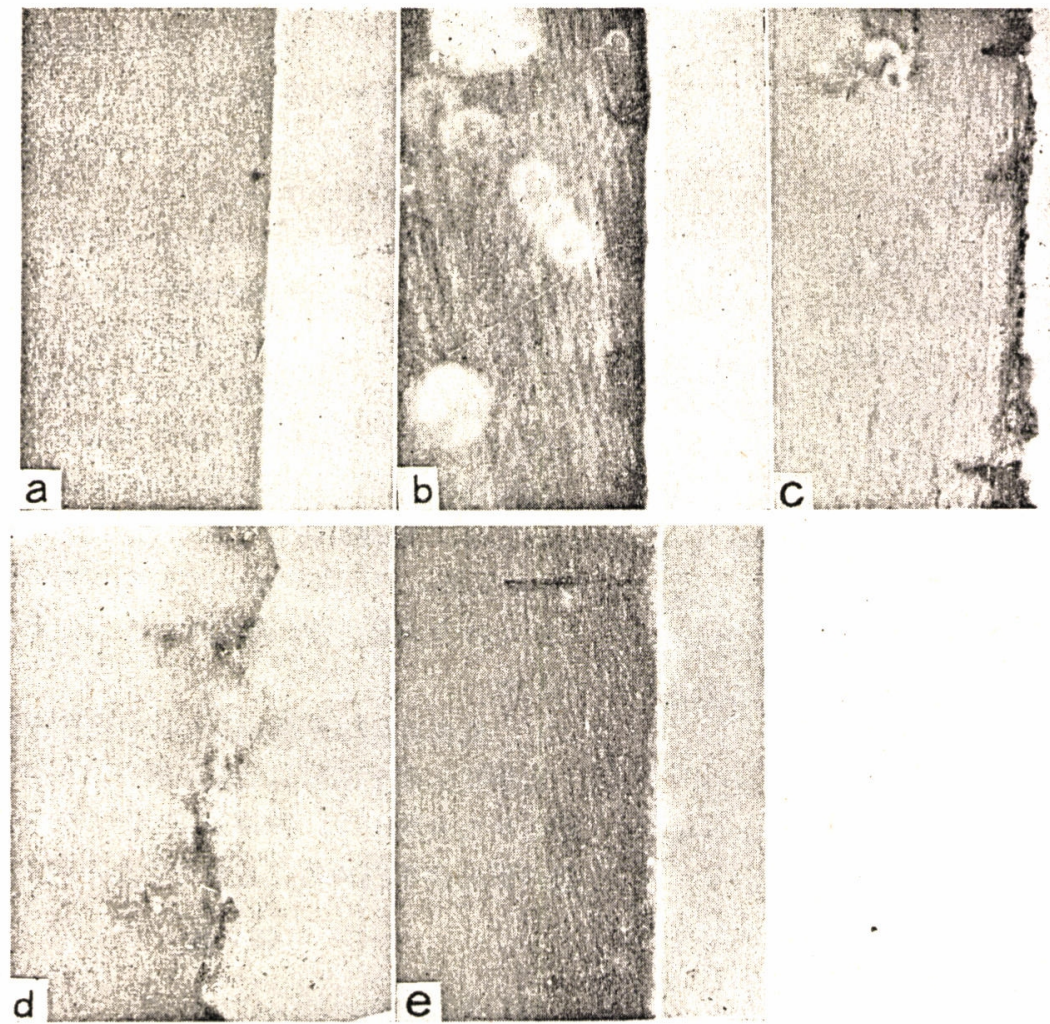
a. 筆積法 錫簿剝離後表面削

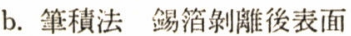
c. 筆積法 錫䈃剝離後表面 除研磨す 100 \%アルコール 削除せず $100 \%$ アルコール 削除せず $60 \%$ アルコール
d. 筆積法 錫䇴貼布せず表面 削除せず $100 \%$ アルコール
e. 加圧充填 錫䇴剝離後表 面削除せず $100 \%$ アルコール

図3各種墴寒法によるレジン表面の亀裂の断面

布の不均一にあり, 重合中に吸収した水分はさら に応力の偏在を助長する結果亀裂発生を促がすと 考え, この考え方は, 溶液論を適用すれば理論的 にも説明出来るので最も妥当な考え方であろうと 述べている。

われわれの実験で用いられたのは即時重合レジ ンであるが，錫䇴剥離後仕上げ研磨を行わなかつ た面では，加熱重合レジンと同様に，アルコール のような弱い有機溶剤を作用させただけで亀裂が 発生した。錫箔を貼布しなかつた面にも亀裂の発 生を見たが，その数は少なく，しかも樑さが浅い ことから,この亀裂発生の大きな因子として, レ ジンが重合硬化途中に錫箔によりなんらかの物理 的な抑制を受け，内部に歪が生じたと考えること
ができる。また加圧充填では, 加圧による応力が 加わり，さらに一そう内部にまで歪が生じたもの と考えられる。

2. 仕上げ研磨法と亀裂発生について

1960 年 Körber は, 苛激に研磨したレジン表 面にクロロホルム小滴を作用させると数秒にして 亀裂を生じ, 侵蝕が内部にまでおよぶと報告して いる。1960年 Meyer は, 亀裂発生のメカニズム について次のように説明している。すなわち、レ ジンの鎖状結合は分子の数と長さが均一でないた め結晶体のように並んでいない。機械的な表面仕 上げによる摩摖熱が表面を可塑性にして, 研磨し た方向に分子の位置をずらし，次に急に冷却する と分子は無理に歪んだ状態で静止する。これに有 
機溶媒が作用すると分子間のエネルギーの平衡関 係が破れて，元の状態に戻ろうとするために引裂 かれ, 亀裂となると述へている。さらに亀裂と色 素の付着について実験を行ない，亀裂の発生はレ ジン污染の原因になると云つている。

今回の実験では, 相当の熱が発生すると思われ る方法で仕上げ研磨を行なつたものでもアルコー ルによつて亀裂が発生しなかつた。この事実は, Meyer らの云う研磨は鋭い面を持つた道具で，し かも充分な注水のもとで行なうべきであるとの説 に相反する結果であるが，これは，われわれの扱 つた試片そのものが小さく, 研磨の道具も義歯を 研磨するときのように大きなものを使わなかつた ので, 歪を生しる程の熱が発生しなかつたためで はないかと思われる。

\section{3. 亀裂防止のための臨床的対策}

日常われわれの臨床を子りかえつてみるに，筆 積み法によつてレジンを填塞した後に，毎回錫箔 を貼布しているが，この䇴を剝離したままの面は 亀裂を発生しやすい歪を含んでいる。しかし前述 の実験成績で明らかなごとく，䄳を内蔵している と思われる表層は $50 \mu$ 以内であるから，これだ け削除してじまえば，削除した面にまた亀裂が生 ずることはない。従つて, 充填時 $50 \mu$ 以上にや や過剩に盛り上げ，仕上げ研磨時にその量を削除 すればよいことになる。錫䇴を貼布しないとレジ ンの硬度が低下することは, さきに渡部 ${ }^{101}$ の指摘 するところでもあり，錫䇴はやはり使用す心゙きで ある。

仕上げ研磨の方法については, 従来総山は加熱 重合レジンについての報告に基づいて，レジン填 塞後の仕上げ研磨は, 注水下になるべく発熱をさ けて行なうよう指示してきた。しかし今回の実験 成績より，レジン充堤物のような比較的小さなも のを研磨するときには, 必ずしも注水を必要とせ ず，乾燥したままの状態で仕上げ研磨を行なつて も臨床上有害でないということが判つた。注水を しないで研磨をすれば，充填物も良く見え，その 辺縁の仕上げなども一そう容易になると思う。し かしながら，乾いたラバーカップなどをこすりつ
けるようにして研磨をすれば，その表面は非常に 粗造になり，レジン充填の特徴である色調, 透明 度も失われ，しかも污物の停滞も起り易くなる。 従つて, 充填物辺縁の仕上げを終つた後の研磨は やはり浮石末泥および亜鉛華泥を充分に使つて慎 重に行うべきであると思う。

\section{総括ならびに結論}

メタアクリル酸即時重合レジン充填物の変色の 原因として，レジン自体の化学的変化および外部 からの污染が考えられる。この污染の有力な原因 となり得るレジン充填物表面の亀裂発生について 実験を行なつた。

硝子管を用いてそれに無色の透明即時重合レジ ンを充填した。その試片の表面にアルコールを作 用させて亀裂を発生せしめ, ヨード染色を施して それを観察した。さらに断面について亀裂の哚さ をも測り，次のような知見を得た。

1. 筆積み法で填塞し，錫箔を剝離したままの 表面では $60 \%$ 以上のアルコールで亀裂を生じた。 亀裂の深さは平均 $40 \mu$, 最大 $49 \mu$ であつた。

2. 筆積み法で填塞し，錫箔を貼布しなかつた ものでも $60 \%$ \%上のアルコールで亀裂を生じた が，その発生度も梁さも前者に比しやや少ないよ うであつた。

3. 加圧充填法によるものでは，錫箔剝離後研 磨しない表面では $40 \%$ 以上のアルコールで亀裂 の発生を見た。またその深さは平均 $75 \mu$ 位で筆 積み法によるものよりもはるかに深かつた。

4. 筆積み法による填塞では, 錫䇴剝離後表面 を $50 \mu$ 程削除研磨することによつて亀裂の発生 を予防することができる。

5. 即時重合レジンを筆積み法によつて塡塞し たものでは，乾いたバーやポイントで仕上げをし ても亀裂発生を増大する心配はないことが判つ た。

稿を終るにあたり，御指導ならびに御校閱を晹つた総 山教授に感謝の意を表するととるに終始御嗳助を顶い た本教室只各位に心から御礼申し上げます。また本实験 のために，特に村料を寄赠下さいました松風陶兆製造株 
式会社に深甚なる謝意を表します。

\section{文 献}

1）総山孝雄：レジン充填, 77, 京都, 1961, 永末 書店.

2) 総山, 岩本, 黒須, 渡部, 稻葉 : レジン充填の臨 床成績, 歯材器学誌, $3: 172,1959$.

3) Skinner, E. W.: The Science of Dental Materials, Philadelphia, 185, 1960, W.B. Saunders Co.

4) W. T. Sweeney, E. L. Yost and J. G. Fee : Physical properties of plastic teeth. J. A. D. A. Vol. 56, June 1958.

5）河野寿雄：急硬化樹脂による義歯床修理につい $\tau$, 歯材器学誌, $4: 1,1959$.
6) Körber, E. : Obserflächebearbeitung zahnärztlicher Kunststoffe. D. Z. Z. 15, 562, 1960.

7) Meyer, H. : Uber Verfarbungen an der Oberflächen von Prothesenkunststoffen infolge fehlerhafter Bearbeitung mit Berüeksichtigung der sogenanten Spannungsrisse, D. Z. Z., $15: 572$, 1960.

8）吉田, 山本, 長野, 大野: 根管治療薬のレジンに およぼす影響について（第 1 報），保存学会例会 講演, 小倉, 1960, 2.

9）亀田, 水野, 鶴巻, 一つ子, 宮本, 岡戸, 清水, 永井 : 義歯床用レジンの刍裂発生原因について, 歯材器学誌, $3: 163,1959$.

10）渡部光太郎：レジン充堤の硬度に関する研究, 保 存学誌, $2: 1,1959$. 